\author{
Н. М. Гузьо ${ }^{1}$, Н. П. Ковальська ${ }^{2}$, А. Р. Грицик ${ }^{1}$ \\ ІВАНО-ФРАНКІВСЬКИЙ НАЦІОНАЛЬНИЙ МЕДИЧНИЙ УНІВЕРСИТЕТ ${ }^{1}$ \\ НАЦІОНАЛЬНИЙ МЕДИЧНИЙ УНІВЕРСИТЕТ ІМЕНІ О. О. БОГОМОЛЬЦЯ², КИЇВ
}

\title{
ДОСЛІДЖЕННЯ ДУБИЛЬНИХ РЕЧОВИН ПАРИЛА ЗВИЧАЙНОГО
}

Вступ. В Україні зростає чотири види рослин роду Парило. з усіх видів найрозповсюдженішим є парило звичайне (Agrimonia eupatoria L.). Рослина має широкий спектр фрармакологічної активності - гепатозахисну, жовчогінну, в'яжучу, протизапальну, протимікробну, противірусну, сечогінну, цукрознижувальну.

Мета дослідження - вивчити таніни у траві парила звичайного залежно від місця зростання і визначити локалізацію дубильних речовин у свіжих листках за допомогою мікрохімічних реакцій.

Методи дослідження. Об'єкти вивчення - водні витяжки з висушеної трави та свіжі листки парила звичайного. Вміст танінів визначали спектрофотометричним методом за ДФУ 2.0.1. Якісний склад $i$ кількісний вміст компонентів дубильних речовини у досліджуваному об'єкті визначали методом високоесрективної рідинної хроматографрії на хроматографрі Agilent 1200 3D LC System Technologies (США). Для проведення мікрохімічних реакцій виготовляли поперечні зрізи через черешок і центральну жилку листка. зрізи обробляли 1 \% розчином фрерум (III) амонію сульфрату. Тимчасові препарати розглядали у світловому тринокулярному мікроскопі XSP-146T фрірми “ULAB”. Фотографували зрізи за допомогою фотокамери CanONEOS 550.

Результати й обговорення. Вміст танінів у перерахунку на пірогалол у траві парила звичайного коливався в межах 1,60-2,10 \% залежно від місця зростання. Методом високоефективної рідинної хроматографрії у траві парила звичайного ідентифріковано такі складові дубильних речовин: два фррагменти гідролізованих дубильних речовин, чотири простих катехіни, один складний катехін. Найбільше в траві парила звичайного виявлено епікатехіну й епігалокатехіну. Результати мікроскопічних досліджень показали, що за допомогою мікрохімічних реакцій (з 1 \% водним розчином фрерум (III) амонію сульфрату) можна визначити на поперечному зрізі черешка і листка парила звичайного локалізацію конденсованих та гідролізованих дубильних речовин.

Висновки. Методом спектрофротометрії встановлено, що кількісний вміст танінів у висушеній траві парила звичайного, залежно від місця зростання, коливається в межах 1,67-2,10 \%. Методом високоефрективної рідинної хроматографрії виявлено, ідентифріковано і визначено кількісний вміст компонентів дубильних речовин у траві парила звичайного. Встановлено локалізацію дубильних речовин у різних місцях на поперечних зрізах черешка і листкової пластинки парила звичайного.

КЛЮЧОВІ СЛОВА: парило звичайне; таніни; конденсовані та гідролізовані дубильні речовини; спектрофотометрія; високоефективна рідинна хроматографія; мікрохімічні реакції.

ВСТУП. До роду Парило (Agrimonia L.) родини розові (Rosaceae) належить 10 видів, які поширені в помірній зоні Північної півкулі, Південній Америці, а також у горах під тропіками [1]. В Україні зростає чотири види рослин роду Парило $[1,2] .3$ усіх видів найрозповсюдженішим $€$ парило звичайне (Agrimonia eupatoria L.).

Рослина має широкий спектр фрармакологічної активності - гепатозахисну, жовчогінну, в'яжучу, протизапальну, протимікробну, противірусну, відхаркувальну, сечогінну, кровоспинну, антигельмінтну, цукрознижувальну [1-3]. Крім (с) Н. М. Гузьо, Н. П. Ковальська, А. Р. Грицик, 2019. цього, її біологічно активні речовини нормалізують обмін речовин, рефллекторно підсилюють секрецію залоз травного тракту, поліпшують апетит [1, 4, 5].

За даними літератури, парило звичайне містить велику кількість різноманітних біологічно активних речовин: танінів, фрлавоноїдів, терпеноїдів, кумаринів, сапонінів, вуглеводів, органічних кислот та ін. [3].

Згідно з різними джерелами літератури, кількісний вміст дубильних речовин у надземній частині рослини коливається в межах 1,5-8,9 \% $[1,4,6]$. 
Українські науковці Г. С. Напраснікова та ін. методом абсорбційної спектрофротометрії визначили кількісний вміст у траві парила звичайного дубильних речовин у перерахунку на пірогалол (2,01 \%) [6]. Дубильні речовини рослини представлені двома групами: конденсованими і гідролізованими танінами [6].

Мета дослідження - вивчити таніни у траві парила звичайного залежно від місця зростання і визначити локалізацію дубильних речовин у свіжих листках за допомогою мікрохімічних реакцій.

МЕТОДИ ДОСЛІДЖЕННЯ. Об'єКТамИ ВИвчення були водні витяжки з висушеної трави та свіжі листки парила звичайного. Сировину заготовляли під час масового цвітіння рослини в Івано-Франківській і Тернопільській областях у 2016 p.

Вміст танінів визначали спектрофротометричним методом за реакцією з фросфорномолібденово-вольоррамовим реактивом у перерахунку на пірогалол відповідно до ДФУ 2.0.1 [7-9].

Якісний склад і кількісний вміст компонентів дубильних речовини у досліджуваному об'єкті визначали методом високоефрективної рідинної хроматографії (BEPX) на хроматографрі Agilent 1200 3D LC System Technologies (США) [9-13].

Як рухому фазу використовували: сольвент А (0,1 \% трисрлуороцтова кислота, 5 \% ацетонітрил та вода очищена $\mathrm{P}, \mathrm{pH}$ розчину - 2,08) та сольвент В (0,1% трифрлуороцтова кислота й ацетонітрил). Режим хроматограсрування: максимальна швидкість подачі рухомої фрази 0,1 мл/4он; максимальний робочий тиск елюента - 400 bar (40 кПа); температура термостата колонки - $25^{\circ} \mathrm{C}$; об'єм введеної проби -5-20 мкл, час хроматографрування - 40 хв. Елюювання градієнтне: 0 хв 100 \% “В”, 8 хв 12 \% "В”, 10 хв $12 \%$ "В", 15 хв $25 \%$ "В", 20 хв $25 \%$ "В", 25 хв 75 \% "В”, 28 хв $75 \%$, 29 хв $100 \%$. Час сканування - 0,6 с, діапазон детектування - 190-400 нм, довжина хвилі - 280, 255 нм.

Пробопідготовку проводили таким чином: зважували подрібнену лікарську рослинну сиро- вину масою 1 г (точна наважка), екстрагували 50 мл $95 \%$ розчину метанолу в ультразвуковій бані при $80 \mathrm{KHz}$ та $45^{\circ} \mathrm{C}$ протягом 30 хв. Екстракт охолоджували і фрільтрували, фрільтрат упарювали при $50{ }^{\circ} \mathrm{C}$ у роторному випаровувачі. Сухий залишок у 100 мл мобільної фази А перед хроматограсруванням фрільтрували через мембранний фрільтр з діаметром пор 0,45 мкм.

Для проведення мікрохімічних реакцій виготовляли поперечні зрізи через черешок і центральну жилку листка за допомогою леза. Зрізи обробляли 1 \% розчином ферум (III) амонію сульфрату. Тимчасові препарати розглядали в світловому тринокулярному мікроскопі XSP-146T фрірми "ULAB" при збільшенні в 40, 100, 400 і 1000 разів. Фотографували зрізи за допомогою дзеркальної фротокамери CanonEOS 550 [14].

РЕЗУЛЬТАТИ Й ОБГОВОРЕННЯ. РеЗУЛЬтаТИ визначення вмісту танінів у висушеній сировині парила звичайного залежно від місця зростання наведено в таблиці.

Як свідчать одержані результати, вміст танінів у перерахунку на пірогалол у сировині парила звичайного коливався в межах 1,60-2,10 \% залежно від місця зростання.

За результатами ВЕРХ-аналізу, в досліджуваному об'єкті ідентифіковано та визначено кількісний вміст компонентів дубильних речовин (рис. 1).

Методом BEPX у траві парила звичайного ідентисріковано такі складові дубильних речовин: два фррагменти гідролізованих дубильних речовин (кислоти галова й елагова - 0,008 і 0,007 \% відповідно), чотири простих катехіни (галокатехін - 0,21 \%, епігалокатехін - 0,97\%, катехін 0,38 \%, епікатехін - 1,16 \%), один складний катехін (епікатехін галат - 0,63%). У траві парила звичайного найбільше виявлено епікатехіну й епігалокатехіну - 1,16 і 0,97 \% відповідно.

Локалізацію дубильних речовин визначали на поперечних зрізах черешка і листкової пластинки (рис. 2-4). Мікропрепарати поміщали послідовно на 5 хв у 1 \% розчин фрерум (III) амонію сульрату та воду очищену.

Таблиця - Кількісний вміст танінів у траві парила звичайного залежно від місця зростання

\begin{tabular}{|l|c|}
\hline \multicolumn{1}{|c|}{ Місце зростання сировини } & $\begin{array}{c}\text { Вміст танінів, \%, } \\
\overline{\mathrm{x}} \pm \Delta \overline{\mathrm{x}} \mathrm{n}=9\end{array}$ \\
\hline Окол. с. Вовчинці, Тисменицький р-н, Івано-Франківська обл. & $1,67 \pm 0,02$ \\
\hline Окол. с. Богородичин, Коломийський р-н, Івано-Франківська обл. & $2,10 \pm 0,02$ \\
\hline Окол. с. Угорники, Коломийський р-н, Івано-Франківська обл. & $2,07 \pm 0,02$ \\
\hline Окол. смт Отинія, Коломийський р-н, Івано-Франківська обл. & $1,99 \pm 0,02$ \\
\hline Окол. с. Ісаків, Тлумацький р-н, Івано-Франківська обл. & $1,87 \pm 0,02$ \\
\hline Окол. с. Більче-Золоте, Борщівський р-н, Тернопільська обл. & $1,75 \pm 0,02$ \\
\hline Окол. с. Жилинці, Борщівський р-н, Тернопільська обл. & $1,81 \pm 0,02$ \\
\hline Окол. с. Ланівці, Борщівський р-н, Тернопільська обл. & $1,94 \pm 0,02$ \\
\hline \hline
\end{tabular}



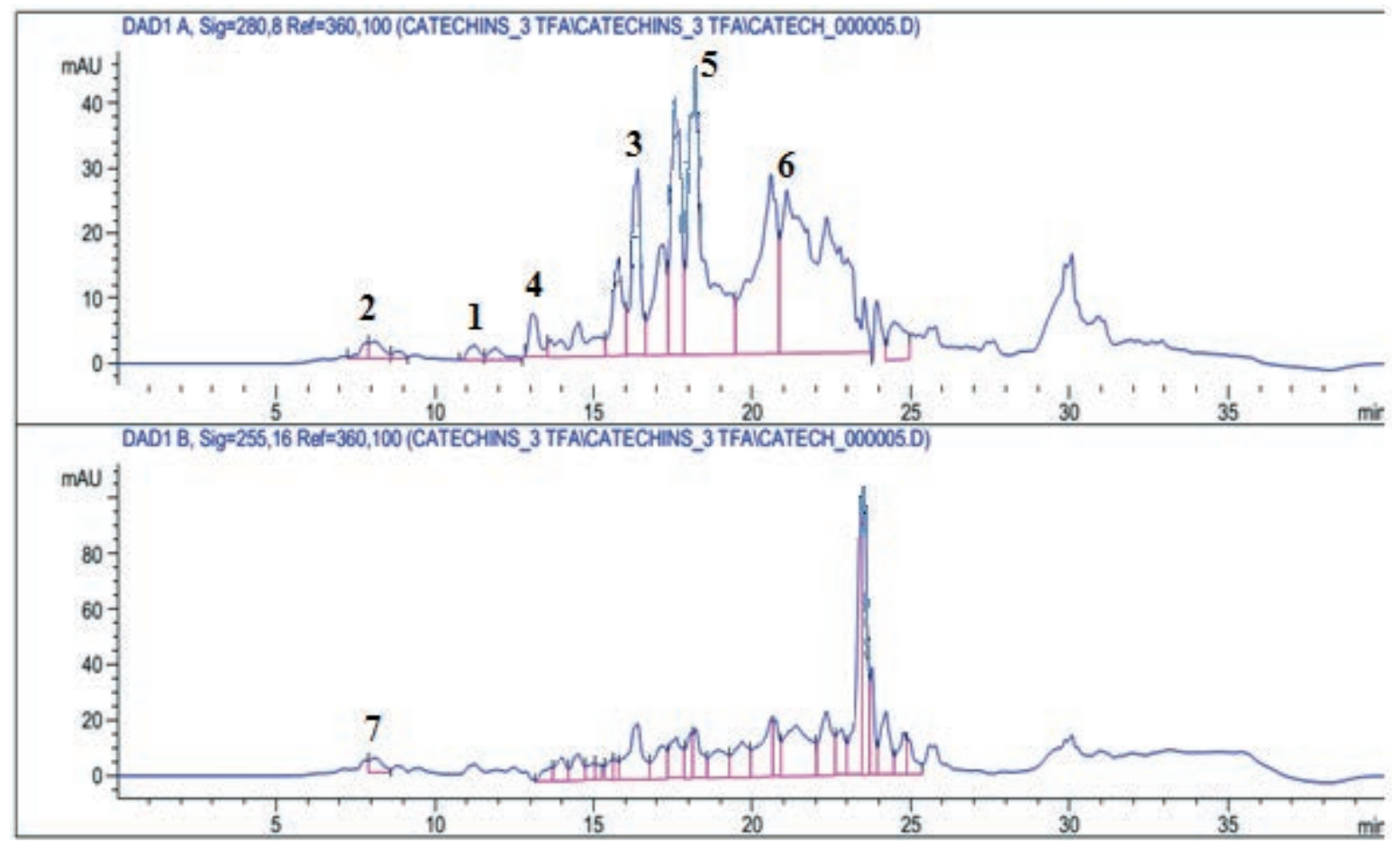

Рис. 1. ВЕРХ-хроматограма компонентів дубильних речовин трави парила звичайного при $\lambda=280$ нм: $1-$ галокатехін; 2 - кислота галова; 3 - катехін; 4 - епігалокатехін; 5 - епікатехін; 6 - епікатехін галат; при $\lambda=255$ нм: 7 - кислота елагова.

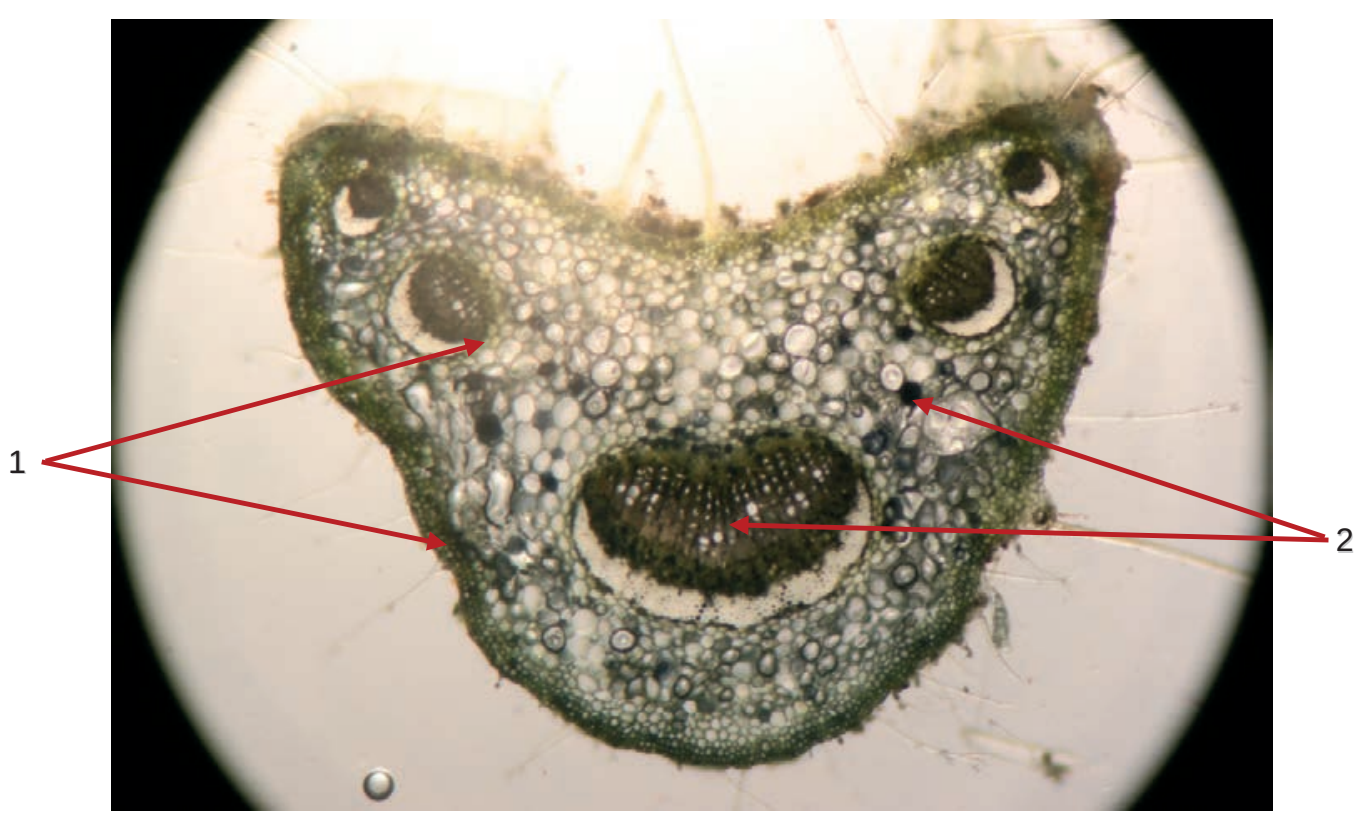

зб. $1 \times 40$

Рис. 2. Мікрохімічна реакція виявлення дубильних речовин на поперечному зрізі черешка парила звичайного: 1 локалізація конденсованих дубильних речовин; 2 - локалізація гідролізованих дубильних речовин.

Конденсовані дубильні речовини (рис. 3) 3 1 \% водним розчином ферум (III) амонію сульфату утворюють чорно-зелене забарвлення і локалізуються під епідермою в міжклітинному просторі коленхіми, в 1-2 рядах паренхімних клітин навколо кожного провідного пучка, а також у ділянках фрлоеми провідних пучків.
Гідролізовані дубильні речовини (рис. 4) 3 1 \% водним розчином фрерум (III) амонію сульсрату утворюють чорно-синє забарвлення і локалізуються в ділянках ксилеми провідних пучків у великих клітинах-ідіобластах, які розміщені в 1-2 ряди поміж судинами. Поодинокі великі клітини з гідролізованими дубильними речовинами 

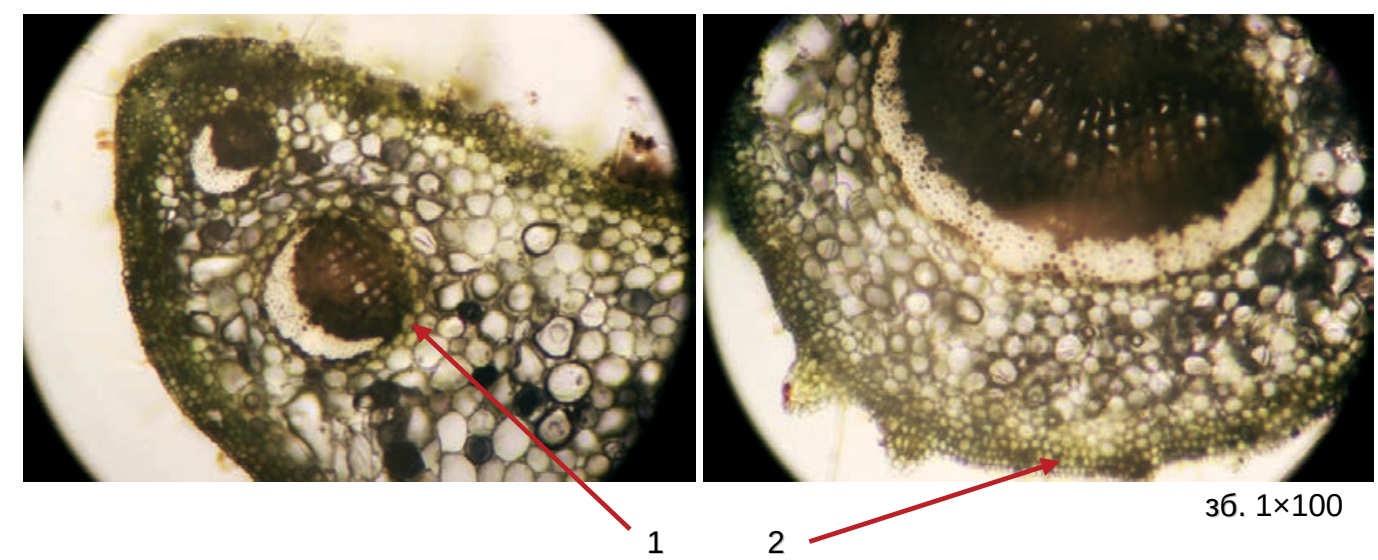

Рис. 3. Мікрохімічна реакція виявлення конденсованих дубильних речовин на поперечному зрізі листка парила звичайного: 1 - в паренхімних клітинах навколо провідного пучка; 2 - в міжклітинному просторі коленхіми.
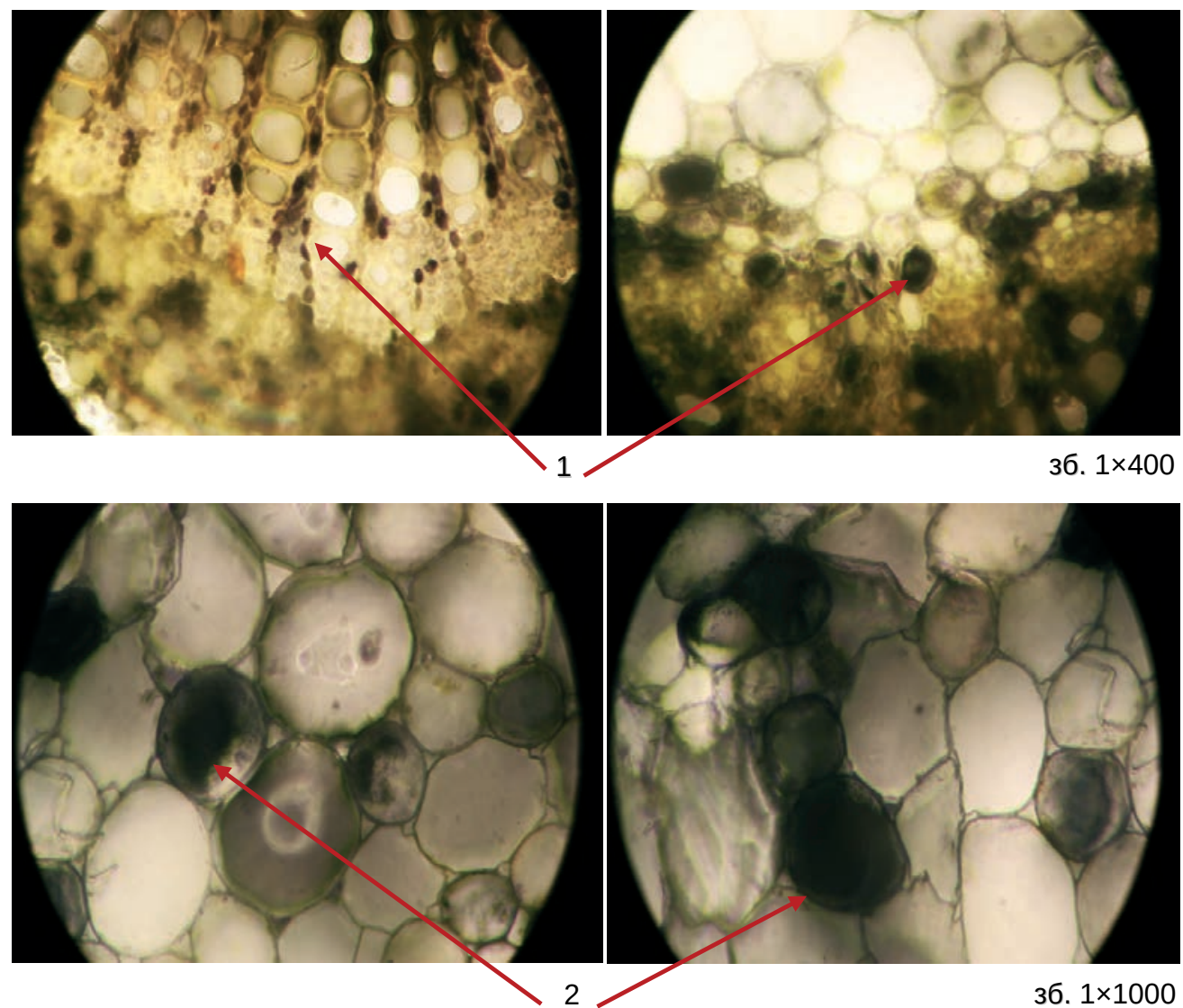

Рис. 4. Мікрохімічна реакція виявлення гідролізованих дубильних речовин на поперечному зрізі листка парила звичайного: 1 - в ділянках ксилеми провідних пучків; 2 - в паренхімній тканині.

виявлено в паренхімній тканині, що виповнює черешок.

Результати проведених досліджень дозволяють визначити локалізацію одночасно конденсованих та гідролізованих дубильних речовин на поперечному зрізі черешка і листка парила звичайного.

ВИСНОВКИ. 1. Методом спектрофотометрії визначено кількісний вміст танінів у висушеній траві парила звичайного залежно від місця зростання.

2. Встановлено, що кількісний вміст танінів у перерахунку на пірогалол у траві парила звичайного, зібраного в різних місцях зростання, коливається в межах 1,67-2,10 \%.

3. Методом ВЕРХ виявлено, ідентифріковано та встановлено кількісний вміст компонентів дубильних речовин у траві парила звичайного (кислоти галової, епігалокатехіну, галокатехіну, 
катехіну, епікатехіну, епікатехін галату, кислоти елагової).

4. Визначено локалізацію дубильних речовин на поперечних зрізах черешка і листкової пластинки. Встановлено, що конденсовані дубильні речовини локалізуються під епідермою в міжклітинному просторі коленхіми, в 1-2 рядах паренхімних клітин навколо кожного провідного пучка, а також у ділянках фрлоеми провідних пучків; гідролізовані дубильні речовини - в ділянках ксилеми провідних пучків у великих клітинахідіобластах, які розміщені в 1-2 ряди поміж су- динами. Поодинокі великі клітини з гідролізованими дубильними речовинами виявлено в паренхімній тканині, що виповнює черешок.

Отже, як допоміжний показник при визначенні тотожності трави парила звичайного ми запропонували методику встановлення локалізації дубильних речовин за допомогою мікрохімічної реакції з 1 \% розчином фрерум (III) амонію сульфрату, що дозволяє за результатом цієї реакції дисреренціювати на поперечному зрізі свіжої сировини різні групи дубильних речовин.

\section{СПИСОК ЛІТЕРАТУРИ}

1. Лікарські рослини : енцикл. довід. / відп. ред. А. М. Гродзінський. - К., 1990. - С. 327.

2. Визначник рослин УРСР / за ред. М. В. Клокова. - К. ; Х. : Урожай, 1950. - С. 378-379.

3. Повний атлас лікарських рослин / [уклад. І. С. Алєксєєв]. - К. : ТОВ "Видавництво Глорія", 2018. - С. 164.

4. Перспективні рослини Карпатського регіону 3 гепатопротекторними та жовчогінними властивостями / А. Р. Грицик, Н. П. Цвеюк, Н. М. Лейбенко, У. Б. Сікорин // Запорож. мед. журн. - 2004. - 2, № 1. C. 99-100.

5. Растительные ресурсы СССР. Цветковые растения, их химический состав, использование / [ред П. Д. Соколов]. - Л., 1987. - С. 19-21.

6. Напраснікова Г. С. Визначення якісного складу фенольних сполук Agrimonia eupatoria L. / Г. С. Напраснікова, І. М. Владимирова, В. А. Георгіянц // Актуальні питання створення нових лікарських засобів : матеріали Всеукр. наук.-практ. конф. студентів та молодих вчених (Харків, 21-22 квіт. 2011 р.). - Х., 2011. - С. 97.

7. Дослідження френольних сполук хризантеми садової багаторічної (Chrysanthemum $\times$ hortorum Bailey) / С. М. Марчишин, О. Л. Демидяк, О.В.Полонець, М. С. Гарник // Мед. та клініч. хімія. -2016. - 18 № 2 (67). - С. 48-53.

8. Мусієнко С. Г. Дослідження фенольних сполук сировини лавра благородного / С. Г. Мусієнко, В. С. Кисличенко // Зб. наук. праць співроб. НМАПО

REFERENCES

1. Hrodzinskyi, A.M. (Ed.). (1990). Likarski roslyny: Entsyklopedychnyi dovidnyk [Medicinal plants: encyclopedic reference book]. Kyiv [in Ukrainian].

2. Klokov, M.V. (1950). (Ed.). Vyznachnyk roslyn URSR [The determinant of plants of the USSR]. Kyiv; Kharkiv: Urozhai [in Ukrainian].

3. Alieksieiev, I.S. (Comp). Povnyi atlas likarskykh roslyn [Full atlas of medicinal plants]. Kyiv: TOV "Vydavnytstvo Hloriia" [in Ukrainian]. імені П. Л. Шупика. - 2014. - Вип. 23 (4). - С. 341344.

9. Державна Фармакопея України / Державне підприємство "Український науковий фрармакопейний центр якості лікарських засобів”. - 2-ге вид. Харків : Державне підприємство "Український науковий фрармакопейний центр якості лікарських засобів”, 2015. - 1. - 1128 с.

10. Investigation of phenolic compounds of Primula veris L. / L. G. Shostak, S. M. Marchyshyn, S. S. Kozachok, R. V. Karbovska // Journal of Education, Health and Sport. - 2016. - 6, No. 5. - P. 424-432.

11. Kozachok S. Determination of the constituents of tannins in Hemerocallis species by HPLC in modified roots / S. Kozachok, S. Marchyshyn, O. Zarichanska // Book of abstracts of the $9^{\text {th }}$ international symposium on chromatography of natural products. Lublin (Poland), May 26-29; 2014. - P. 128.

12. Sensitive Determination of Catechins in Tea by HPL. Thermo scientific. DIONEX corporation. - 2011. AN 275. -9 p.

13. Weerasak Samee Simultaneous determination of gallic acid, catechin, rutin, ellagic acid and quercetin in flower extracts of Michelia alba, Caesalpinia pulcherrima and Nelumbo nucifera by HPLC - Weerasak Samee, Suwanna Vorarat // Thai pharmaceutical and health science journal. - 2007. - 2, No. 2. - P. 131-137.

14. Доля В. С. Мікроскопічний на мікрохімічний аналіз лікарської рослинної сировини / В. С. Доля, $€$ Є. Книш, В. І. Мозуль. - Запоріжжя : ЗДУ, 2003. 297 c.

4. Hrytsyk, A.R., Tsveiuk, N.P., Leibenko, N.M., \& Sikoryn, U.B. (2004). Perspektyvni roslyny Karpatskoho rehionu z hepatoprotektornymy ta zhovchohinnymy vlastyvostiamy [Perspective plants of the Carpathian region with hepatoprotective and choleretic properties]. Zaporozhskyy med. zhurnal - Zaporozhye Medical Journal, 2 (1), 99-100 [in Ukrainian].

5. Sokolov, P.D. (1987). Rastitelnye resursy SSSR. Tsvetkovye rasteniya, ykh khimicheskiy sostav, ispol- 
zovanye [Plant resources of the USSR. Flowering plants, their chemical composition, use]. Leningrad [in Russian].

6. Naprasnikova, H.S., Vladymyrova, I.M., Heorhiiants, V.A. (2011). Vyznachennia yakisnoho skladu fenolnykh spoluk Agrimonia eupatoria L. [Determination of the qualitative composition of phenolic compounds of Agrimonia eupatoria L.]. Aktualni pytannia stvorennia novykh likarskykh zasobiv: materialy Vseukr. nauk.-prakt. konf. studentiv ta molodykh vchenykh - Topical Issues of Creating New Medicines: All-Ukrainian Materials. Research Practice Conf. Students and Young Scientists. Kharkiv, April, 21-22 [in Ukrainian].

7. Marchyshyn, S.M., Demydiak, O.L., Polonets, O.V., \& Harnyk, M.S. (2016). Doslidzhennia fenolnykh spoluk khryzantemy sadovoi bahatorichnoi (Chrysanthemum $\times$ hortorum Bailey) [Study of phenolic compounds of chrysanthemum garden perennial (Chrysanthemum $\times$ hortorum Bailey)]. Med. ta klinich. khimiia - Medical and Clinical Chemistry, 18, 2 (67), 4853 [in Ukrainian].

8. Musiienko, S.H., \& Kyslychenko, V.S. (2014). Doslidzhennia fenolnykh spoluk syrovyny lavra blahorodnoho [Investigation of phenolic compounds of the raw material of laurel noble]. Zb. nauk. prats spivrobitnykiv NMAPO imeni P.L. Shupyka - Collection of Scientific Works of Workers of the NAPGE named after P.L. Shupyk, 23 (4), 341-344 [in Ukrainian].

9. Derzhavna Farmakopeia Ukrainy. Derzhavne pidpryiemstvo "Ukrainskyi naukovyi farmakopeinyi tsentr yakosti likarskykh zasobiv". 2-e vyd. [State Pharmacopoeia of Ukraine. State Enterprise "Ukrainian Scientific Pharmacopoeial Center for Medicinal Products Quality". 2nd kind]. Kharkiv: Derzhavne pidpryiemstvo "Ukrainskyi naukovyi farmakopeinyi tsentr yakosti likarskykh zasobiv" [in Ukrainian].

10. Shostak, L.G., Marchyshyn, S.M., Kozachok, S.S., \& Karbovska, R.V. (2016). Investigation of phenolic compounds of Primula veris L. Journal of Education, Health and Sport, 6 (5), 424-432.

11. Kozachok, S., Marchyshyn, S., \& Zarichanska, O. (2014). Determination of the constituents of tannins in Hemerocallis species by HPLC in modified roots. Book of abstracts of the 9th international symposium on chromatography of natural products. Lublin (Poland). May 26-29.

12. (2011). Sensitive Determination of Catechins in Tea by HPL. Thermo scientific. DIONEX corporation.

13. Weerasak Samee (2007). Simultaneous determination of gallic acid, catechin, rutin, ellagic acid and quercetin in flower extracts of Michelia alba, Caesalpinia pulcherrima and Nelumbo nucifera by HPLC - Weerasak Samee, Suwanna Vorarat. Thai Pharmaceutical and Health Science Journal, 2 (2), 131-137.

14. Dolia, V.S., Knysh, Ye.H., \& Mozul, V.I. (2003). Mikroskopichnyi na mikrokhimichnyi analiz likarskoi roslynnoi syrovyny [Microscopic for microchemical analysis of medicinal plant raw materials]. Zaporizhzhia: ZDU [in Ukrainian].

\section{Н. Н. Гузьо ${ }^{1}$, Н. П. Ковальская ${ }^{2}$ А. Г. Грицик ${ }^{1}$ ИВАНО-ФРАНКОВСКИЙ НАЦИОНАЛЬНЫЙ МЕДИЦИНСКИЙ УНИВЕРСИТЕТ НАЦИОНАЛЬНЫЙ МЕДИЦИНСКИЙ УНИВЕРСИТЕТ ИМЕНИ А. А. БОГОМОЛЬЦА², КИЕВ}

\section{ИССЛЕДОВАНИЕ ДУБИЛЬНЫХ ВЕЩЕСТВ РЕПЕЙНИЧКА ЛЕКАРСТВЕННОГО}

\section{Резюме}

Вступление. В Украине растет четыре вида растений рода Репейничек. Из всех видов наиболее распространенным является репейничек лекарственный (Agrimonia eupatoria L.). Pacmeние uмеeт широкий спектр фрармакологической активности - гепатозащитную, желчегонную, вяжущую, противовоспалительную, противомикробную, противовирусную, мочегонную, сахароснижающую.

Цель исследования - изучить танины в траве репейничка лекарственного в зависимости от места произрастания и определить локализацию дубильных веществ в свежих листьях с помощью микрохимических реакций.

Методы исследования. Объекты изучения-водные вытяжки из высушенной травы и свежие листья репейничка лекарственного. Содержание танинов определяли спектрофотометрическим методом по ГФУ 2.0.1. Качественный состав и количественное содержание компонентов дубильных веществ в исследуемом объекте определяли методом высокоэффективной жидкостной хроматографии на хромаmoгpaqpe Agilent 1200 3D LC System Technologies (США). Для проведения микрохимических реакций изготавливали поперечные срезы через черешок и чентральную жилку листа. Срезы обрабатывали $1 \%$ раствором фрерум (III) аммония сульфрата. Временные препараты рассматривали в световом тринокулярном микроскопе XSP-146T фрирмы “ULAB". Фотографрировали срезы с помощью фотокамеры CanonEOS 550.

Результаты и обсуждение. Содержание танинов в пересчете на пирогаллол в траве репейничка лекарственного колебалось в пределах 1,60-2,10 \% в зависимости от места произрастания. Методом высокоэффрективной жидкостной хроматографрии в траве репейничка лекарственного идентифрициро- 
вано такие составляющие дубильных веществ: два фрагмента гидролизированных дубильных веществ, четыре простых катехина, один сложный катехин. Больше всего в траве репейничка лекарственного обнаружено эпикатехина и эпигаллокатехина. Результаты микроскопических исследований показали, что с помощью микрохимических реакций (с 1 \% водным раствором фрерум (III) аммония сульфрата) можно определить на поперечном срезе черенка и листа репейничка лекарственного локализацию конденсированных и гидролизированных дубильных веществ.

Выводы. Методом спектрофотометрии установлено, что количественное содержание танинов в высушенной траве репейничка лекарственного, в зависимости от места произрастания, колеблется в пределах от 1,67-2,10\%. Методом высокоэффрективной жидкостной хроматографии обнаружено, идентифицировано и определено количественное содержание компонентов дубильных веществ в траве репейничка лекарственного. Установлено локализацию дубильных веществ в разных местах на поперечных срезах черенка и листовой пластинки репейничка лекарственного.

КЛЮЧЕВЫЕ СЛОВА: репейничек лекарственный; танины; конденсированные и гидролизированные дубильные вещества; спектрофотометрия; высокоэффективная жидкостная хроматография; микрохимические реакции.

N. M. Huzo ${ }^{1}$, N. P. Kovalska², A. R. Grycyk ${ }^{1}$ IVANO-FRANKIVSK NATIONAL MEDICAL UNIVERSITY ${ }^{1}$ O. BOHOMOLETS NATIONAL MEDICAL UNIVERSITY², KYIV

\section{RESEARCH ON TANNINS OF AGRIMONIA EUPATORIA L.}

\section{Summary}

Introduction. In Ukraine there are four species of plants of the genus Agrimonia L. Of all species, the most common is Agrimonia eupatoria L. The plant has a wide range of pharmacological activity - hepatoprotective, choleretic, astringent, anti-inflammatory, antimicrobial, antiviral, diuretic, hypoglycaemic.

The aim of the study - to investigate the tannins in the agrimony herb, depending on the place of growth and determine the localization of tannins in fresh leaves by microchemical reactions.

Research Methods. Objects of study - water extracts of dried herb and fresh leaves of Agrimonia eupatoria. Determination of tannin content was performed by spectrophotometric method according to SPhU 2.0.1. The qualitative composition and quantitative content of the BAS from the tannin group in the test object were determined by high performance liquid chromatography (HPLC) using Agilent 1200 3D LC System Technologies (USA). Cross sections through the petiole and the central vein of the leaf were made for carrying out microchemical reactions. The sections were treated with a $1 \%$ solution of ferric ammonium sulphate (III). Temporary micropreparations were examined in a light trinocular microscope XSP-146T company ULAB. Photos were taken using a Canon EOS 550.

Results and Discussion. The content of tannins in terms of pyrogallol in the agrimony herb ranges from 1.60 to $2.10 \%$, depending on the place of growth. HPLC in the agrimony herb identified the following components of tannins: two fragments of hydrolysed tannins, four simple catechins, one complex catechin. The most common substances, that were found in the agrimony herb are epicatechin and epigallocatechin. The results of microscopic studies have shown that by means of reaction with $1 \%$ aqueous solution of ferric (III) ammonium sulphate, the localization of condensed and hydrolyzed tannins can be established on the cross section of the petiole and leaf.

Conclusions. The method of spectrophotometry has determined the quantitative content of tannins in the dried agrimony herb depending on the place of growth and ranges from $1.67 \%$ to $2.10 \%$. The HPLC method revealed, identified and quantified the content of tannins in the agrimony herb. The localization of tannins in different places on the cross-sections of the petiole and leaf slices of the agrimony herb was determined.

KEY WORDS: agrimony herb; tannins; condensed and hydrolyzed tannins; spectrophotometry; HPLC; microchemical reactions.

Адреса для листування: Н. М. Гузьо, Івано-Франківський національний медичний університет, вул. Галицька, 2, Івано-Франківськ, 76018, Україна, e-mail: notafarm@ukr.net. 